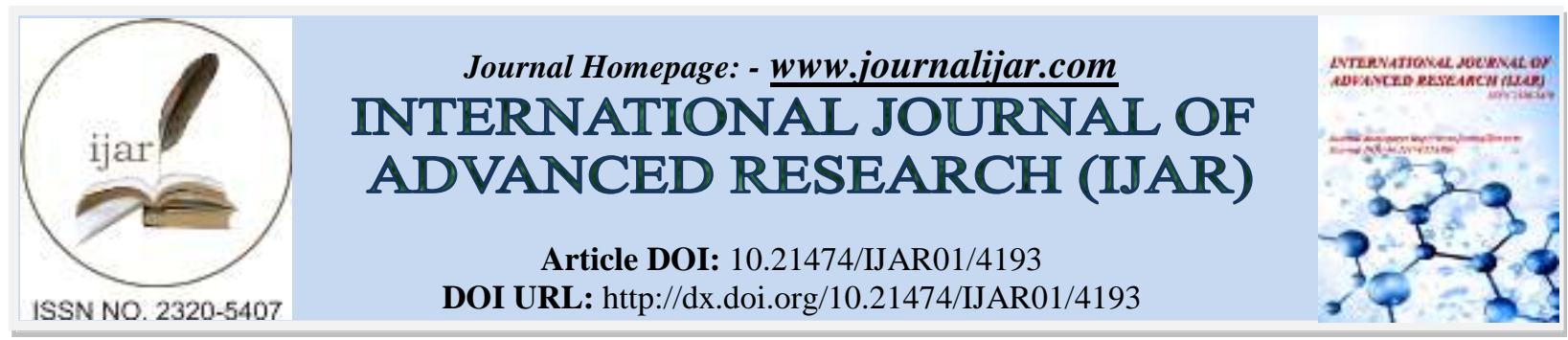

RESEARCH ARTICLE

\title{
AGROBACTERIUM-MEDIATED GENETIC TRANSFORMATION AND REGENERATION FROM LEAF EXPLANTS OF SOLANUM THORVUM (SWARTZ) A MEDICINALLY IMPORTANT PLANT.
}

\author{
${ }^{*}$ Ugandhar T ${ }^{1}$, Odelu G ${ }^{2}$, Parvathi. $\mathrm{D}^{3}$, Anitha Devi $\mathrm{U}^{4}$ and Venkateshwarlu $\mathrm{M}^{5}$. \\ 1. Department of Botany, SRR Govt. Arts \& Science College Karimnagar - 505001 . \\ 2. Department of Botany, Govt. Degree \& P.G. College, Jammikunta, 505122. \\ 3. Department of Botany, Govt. Degree \& P.G.College Narsampet- 506132. \\ 4. Department of Botany, Govt. Degree \& P.G. College for Women Karimnagar- 505001. \\ 5. Department of Botany, University College Kakatiya University Warangal - 506009.
}

\section{Manuscript Info}

Manuscript History

Received: 16 March 2017

Final Accepted: 18 April 2017

Key words:-

Agrobacterium, b-glucuronidase (GUS)

Kanamycin, Cefotoxime, Transgenic

Solanum torvum.
Published: May 2017

\begin{abstract}
Solanum torvum commonly known as turkey berry, devil's-fig, or prickly Solanum is a plant of great economic importance. Its extract, rich in Solanine and Solasodine (steroidal alkaloids) have beneficial effect on bronchial asthma. It is cultivated in tropics for its immature edible fruits. In India the $S$. torvum is used in medicines to cure diabetes, asthma, cholera, bronchitis and dysuria. The fresh or dry leaf and fruit are said to reduce blood cholesterol level. In this plant is susceptible to a number of diseases and pests capable of causing serious crop losses. This problem has been addressed by hybridizing S. torvum plant with wild resistant Solanum species, which present a wild genetic diversity and are source of useful agronomic traits. S. torvum plant tissues present a high morphogenetic potential that is useful for developmental studies as well as for establishing biotechnological approaches to produce improved varieties such as embryo rescue, in vitro selection, somatic hybridization and genetic transformation, In order to generate $S$. torvum leaf explants were cultured on Murashige and Skoog medium containing $(0.5 \mathrm{mg} / \mathrm{L})$ IAA supplemented with BAP, in addition to either $(100 \mathrm{mg} / \mathrm{L})$ Kanamycin and $(200 \mathrm{mg} / \mathrm{L})$ cefotaxime after co-cultivation with disarmed Agrobacterium tumefaciens harboring a plant expression binary vector. Explants cocultivated with $A$. tumefaciens LBA 4404 produced putative transgenic adventitious shoots at $(2.3 \pm 0.4)$ shots/explants, respectively. The transgenic plants were grown to maturity after vernalization in a greenhouse and appeared morphologically normal. Progeny analysis of independent transgenic plants demonstrated that the gus gene was transmitted in a Mendelian pattern in 3 lines, indicating a single copied gene was incorporated into the genome.
\end{abstract}

Copy Right, IJAR, 2017,. All rights reserved.

\section{Introduction:-}

Solanum torvum commonly known as turkey berry, devil's-fig, or prickly Solanum (Pier 2003) is a plant of great economic importance. Its extract, rich in Solanine and Solasodine (steroidal alkaloids) have beneficial effect on 
bronchial asthma. It is cultivated in tropics for its immature edible fruits (Langeland and Burks 1998). Alkaloids are a class of nitrogen compounds structurally diverse, found in all plant groups, curring most of them in angiosperms (Henriques et al., 2002; Hughes and Shanks, 2002). Many species of the Solanaceae have been regenerated by shoot organogenesis using young leaf explants. Solanum surattense (Gupta and Handra, 1982), Solanum candidum, S.quitoense, Solanum sessiliflorum (Hendrix et al., 1987), Solanum melongena (Mukherjee et al., 1991) and Solanum commersonii (Cardi et al., 1993). Arulmozhi and Ramanujam (1997) conducted in vitro culture studies on Solanum trilobatum L. with foliar and stem explants on MS medium containing IAA, BAP and KIN combinations. Madhavan et al., (1999) induced high frequency of shoot regeneration from mature seeds of Solanum trilobatum L. Callus was induced from root and shoot apical region and hypocotyls on MS medium supplemented with 2,4-D. the plant tissue culture methods also provide base for the improvement of crop to induce somaclonal variations, in vitro mutations, herbicide tolerance, di-haploid induction, genetic transformation of economically important genes and development of somatic hybrids, efficient plant regeneration protocol is required. Such advance tech-niques in combination with conventional breeding give a momentum to the improvement of a crop thus, realizing the prospects for future research, relevant literature to attempt has been made to formulate a suitable Protocol for efficient micropropagation from seedling shoot tips explants of S. torvum.

For genetic improvement of plant, we usually use selection method as well as in vitro molecular breeding technique. Plant breeders showing great interest on molecular breeding technique for plant modification genetically because conventional selection method takes long time, tedious and occurs large variation within clones. For molecular breeding based genetic transformation, we know, efficient regeneration systems are prime requirement. Stem segments are used as important explant for genetic transformation system, described in many plant species (e.g., Rastogi and Dwivedi, 2006).

In Some countries, the highest percentage of the acreage of some economically important crops is transgenic; an increasing number of these transgenic varieties are or will soon be generated by Agrobacterium-mediated transformation (Gelvin, 2003). Due to the wide host range Agrobacterium mediated genetic transformation is very popular method for introducing gene of interest into plant. A. tumefaciens as a gene vector is limited to soybean (Hinchee et al., 1988, broad bean (Jelenic et al., 2000), sesame (George et al., 1987) and sunflower (Weber et al., 2003). Brassica is also a suitable host for Agrohacterium spp. (Godwin et al., 1991; Toriyama et.al., 1991). So, the non-oncogenic Agrobacterium strain as a vector (Lin dsey, 1992) can make possible to transfer desired gene in Brassicu. Still now, a little success in genetic transformation has been reported in oil crop due to their recalcitrant in vitro condition (Nisbet and Webb, 1990). The main problem about the Brassica is that, the transformed tissues (callus) are not regenerable and the regenerable tissues (meristematic tissues) arc not transformable. Considering all issues, the objectives of the present study was to develop a reproducible any efficient protocol for the insertion of molecular genes into $S$. torvum through A. tumefaciens vectors and to standardize the periods of pre culture and cocultivation required for transformation and to analyze the putative transgenic plants using histochemical $G U S$ assay.

\section{Material and Methods:-}

Seeds of $S$. torvum collected from the plant grown in the research field. Department of Botany S.R.R. Govt. Arts \& Science College Karimnagar. Dried mature seeds were soaked in sterile distilled water for 24 hours and sterilized with $0.1 \%(\mathrm{w} / \mathrm{v})$ aqueous $\mathrm{HgCl}_{2}$ for 3-5 minutes followed by washing 3 times with sterile distilled water. Later these were dried on sterile on sterile tissue paper under laminar-flow hood 20 seeds per culture bottle were germinated aseptically on Ms basal medium containing 3\%(w/v) sucrose and $0.8 \%(\mathrm{w} / \mathrm{v})$ agar. These culture bottles were incubated at $25 \pm 10 \mathrm{C}$ under $16 \mathrm{~h}$ photoperiod. Light was provided by cool white fluorescent tubes with an intensity of 50-60 Leaf explants from 30 day old seedlings were used for transformation experiments.

\section{Bacterial Strain:-}

The Agrobacterium strain used was LBA 4404 harbon ring a binary plasmid PBIN 19 which has a npt II (Neomycin photo transferase II ) gene and a vid A (gus gene). The Agrobacterium strain was grown on Lury and Bertani (LB) medium plates containing $5.0 \mathrm{gm} / \mathrm{L} \mathrm{NaCl}, 10 \mathrm{gm} / \mathrm{L}$ Bactotryptone, $5 \mathrm{gm} / \mathrm{L}$ Yeast Extract and $100 \mathrm{mg} / \mathrm{L} \mathrm{Kanamycin}$ and the $\mathrm{pH}$ was adjusted to 7.0 and solidified with $7 \mathrm{gm} / \mathrm{L}$ Difco/Bacto Agar.

\section{Transformation and Plant Regeneration:-}

For co-cultivation two colonies from a freshly streaked plate were transferred to $10 \mathrm{ml}$ of Liquid LB medium. Agrobacterium strain LBA 4404 was grown at $28^{\circ} \mathrm{C}$ overnight in LB liquid medium containing $100 \mathrm{mg} / \mathrm{L}$ Kanamycin(KM) with shaking (approx. $250 \mathrm{rpm}$ ). Kanamycin was added since the binary vectors are not 
completely stable in Agrobacterium in the absence of antibiotic selection for transformation, the hypocotyls explants were submerged and gently shaken in the A. tumefaciens suspension for about 10 minutes and blotted dry on a sterile filter paper. Afterwards, they were transferred to shoot regeneration (SR) medium containing MS salts $(0.5$ $\mathrm{mg} / \mathrm{L}) \mathrm{IAA}+(3.0 \mathrm{mg} / \mathrm{L})$ BAP for leaf explants and co cultivated under $16 \mathrm{hr}$. photo period of 50-60 $\mu \mathrm{mol} \mathrm{m}-2 \mathrm{~S}-1$ For 3 days at $25 \pm 2^{\circ} \mathrm{C}$. After co-culture, the explants were washed in the MS liquid medium blotted dry on a sterile filter paper and transferred to the freshly prepared selective SR medium (MS1) supplemented with antibiotics 200 $\mathrm{mg} / \mathrm{L}$ Cefotoxime and $100 \mathrm{mg} / \mathrm{L}$ Kanamycin.(Table-1) Simultaneously a control was also maintained. After 4 weeks, the growing shoots were excised from the primary explants and sub cultured in fresh proliferation selective medium containing $100 \mathrm{mg} / \mathrm{L} \mathrm{KM}$ (MS2). The green healthy shoots from explants were subjected to 2-3 passages of selection by repeated excision of branches and their exposure to selective elongation medium (MS2). The green shoots were transferred to MS medium containing $(0.1 \mathrm{mg} / \mathrm{L})$ with Kanamycin $(100 \mathrm{mg} / \mathrm{L})$ for root induction (Table-2). (Fig I B, C and D)

\section{Culture conditions and Data Analysis:-}

All the cultures were incubated at $25 \pm 2^{\circ} \mathrm{C}$ and $16 \mathrm{hr} / 8 \mathrm{hr}$ photoperiod under $50-60 \mu \mathrm{mol} \mathrm{m}-2 \mathrm{~S}-1$ white fluorescent light. All the experiments were carried out in 10 replicates. The experiments were replaced at least 3 times, keeping all the Parameters unchanged.

\section{Histrochemical Gus Assay:-}

The Histochemical GUS assay was carried out according to Staining was done by placing the tissue into X-gluc, staining buffer in a small vessel, X-Gluc stock was prepared by dissolving X-Gluc $20 \mathrm{mg} / \mathrm{ml}$ in Dimethyl Sulphoxide (DMSO). To make $1 \mathrm{ml}$ of staining buffer $0.85 \mu \mathrm{l}$ sterile distilled water was mixed with $100 \mu \mathrm{l}$ monosodium PO4 (pH-7), $5 \mathrm{ml}$ of X-Gluc stock and $5 \mu \mathrm{l}$ Triton X-100 in an eppendoraff tubes. The sample was incubated overnight at $37^{\circ} \mathrm{C}$. Later these explants were treated with aceto alcohol $(1: 3 \mathrm{v} / \mathrm{v})$ mixture to remove chlorophyll and then fixed in $70 \%$ ethanol. The tissues were examined under stereomicroscope for the evidence of blue cells. X-glucuronide (5-bromo-4- chloro-3-indolyl glucuronide) is colorless but the indoxy product derived after glucoronidase activity undergoes oxidative dimerisation to from an

Insoluble indigo blue (Fig I A).

\section{Results:-}

We have standardization the plant regeneration in $S$. torvum from leaf explants using. MS medium supplemented with $0.5 \mathrm{mg} / \mathrm{L}$ IAA+3.0 mg/L BAP. The combination was routinely used for the present transformation experiments. The explant (Leaf) co-cultivated with A. tumefaciens formed shoots 6 weeks of culture on selective shoot regeneration medium (MS1). The control explants which were not co-cultivated did not produce when cultured on MS1 medium indicating the effective level of Kanamycin (100 mg/L) (Table-2). Kanamycin sensitivity of leaf explants was assessed prior to Agrobacterium transformation to determine the concentration of Kanamycin needed for effective growth of transgenic plants. At $(50 \mathrm{mg} / \mathrm{L})$ Kanamycin caused chlorosis and eventual necrosis in all explants by the end of the fourth week. Whereas concentrations of $(75 \mathrm{mg} / \mathrm{L})$ and $(100 \mathrm{mg} / \mathrm{L})$ Kanamycin completely inhibited the formation of shoot buds. In the present study higher concentration of Kanamycin (100 $\mathrm{mg} / \mathrm{L}$ ) was used for selection of transformants to prevent possible escapes. High percentage of cultures producing green shoots was observed in leaf explants (Table- 2). After four weeks the growing green shoots (Fig I B) from MS1 medium were excised and transferred into MS2 medium for proliferation.

The transformed shoots were multiplied by culturing on MS2 medium containing 100mg/L Kanamycin to confirm the stability of the transgenic shoots. Leaf explants from transgenic plants when cultured on shoot regeneration medium containing Kanamycin showed the plant regeneration thus the stability was also achieved by leaf strip assay. Most of the transgenic clones appeared morphologically normal in comparison with the untransformed plants. The putative transformed shoots which attained $2-3 \mathrm{~cm}$ in length were excised and then transferred to the MS3 medium for rooting (Fig I D).

The leaves from transgenic shoots were subjected to in situ GUS assay (Fig I C). The expression of uid a gene was verified by histochemical staining of the leaf of the transgenic plants. The npt II positive regenerants showed the typical indigo blue colouration of X-Glue treatment while the untransformed ones didn't show GUS activity. Also, more than $33 \%$ and $27 \%$ of the regenerants from leaf explants respectively were Gus positives. These results clearly demonstrate the stability of the transformed plants. 


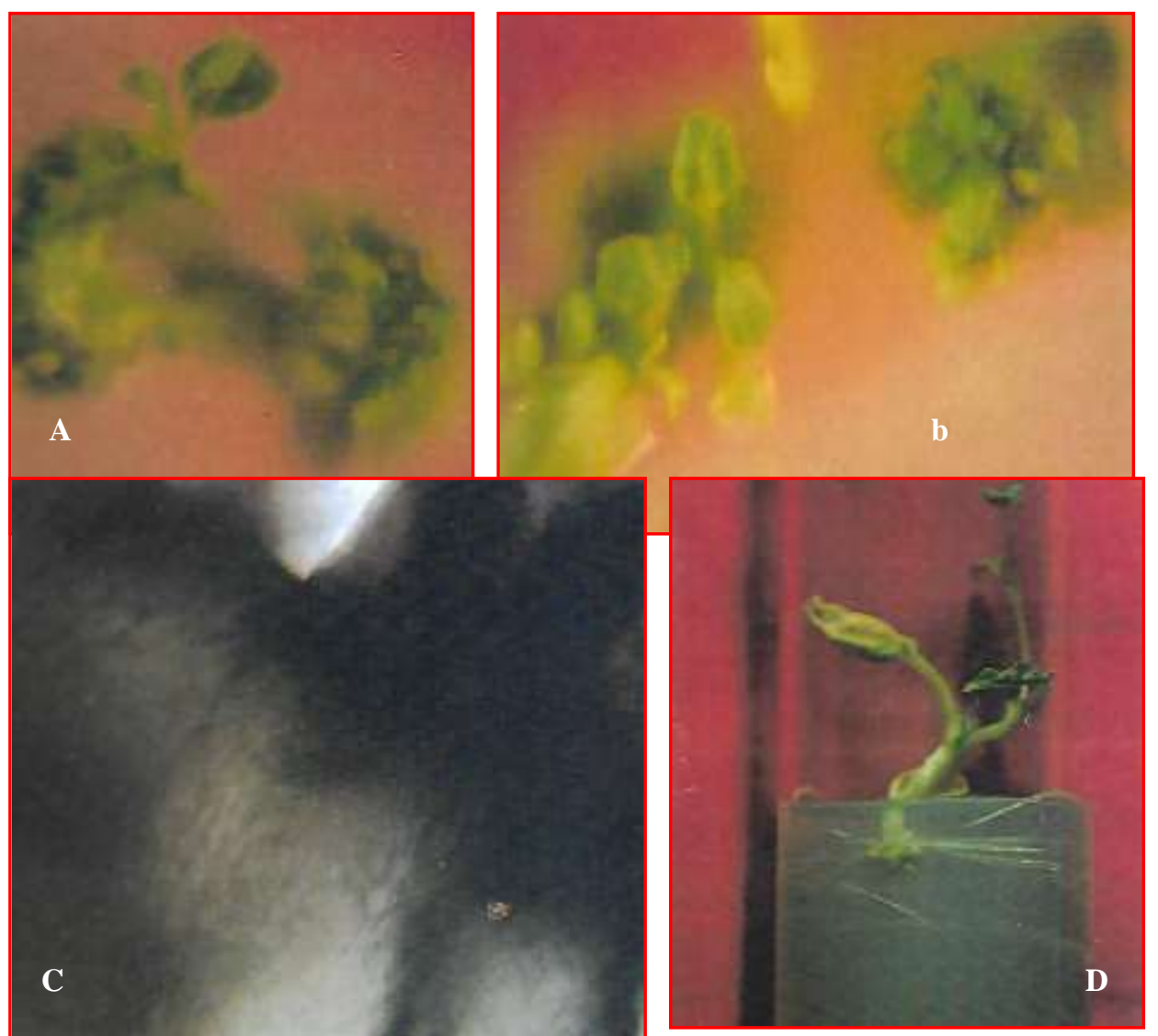

Figure 1:- Plant regeneration from Leaf explants of S.torvum transformed with gus gene

A. Blue colour formation on selection medium with $100 \mathrm{mg} / \mathrm{L}$ Kanamycin

B. Shoots elongated from the Kanamycin resistant from leaf explants after 4 weeks of Culture.

C. GUSexpression in transformed tissue (developing shoots after 6 weeks of culture.

D. In vitro rooting from Kanamycin resistant micro shoots after 8 weeks of culture.

Table 1:- Successive growth media used for the transformation and Selection of Transgenic Shoots from Leaf Explants of $S$. torvum

\begin{tabular}{|l|l|l|l|}
\hline SI No & Steps and Components of Media & MS 1 Medium & MS 2 Medium \\
\hline 1 & Time for A. tumefacience Inoculation & 8 minutes & ---------- \\
\hline 2 & Co-cultivation with A. tumefacience & 2 minutes & $-\cdots------$ \\
\hline 3 & Proliferation of shoots & -------- & $4-5$ Weeks \\
\hline 4 & Kanamycine selection and shoot regeneration & ---------- & $6-7$ Weeks \\
\hline 5 & MS salts gm / L. & 4.5 & 4.3 \\
\hline 6 & Sucrose gm / L & 25.0 & 30.0 \\
\hline 7 & Hormone mg/L. & IAA+BAP $(0.5)+(3.0)$ & IAA+BAP $(0.5)+(3.0)$ \\
\hline 8 & Cefotaxime mg/L. & -------- & 200 \\
\hline 9 & Kanamycine mg / L. & -------- & 100 \\
\hline 10 & pH & 5.8 & 5.8 \\
\hline 11 & Agar-Agar gm/L & 8.0 & 8.0 \\
\hline
\end{tabular}


Table 2:- Successive growth media used for the transformation and selection of Transgenic shoots from Leaf explants of $S$. torvum

\begin{tabular}{|l|l|l|l|l|l|}
\hline Explant & Strain & $\begin{array}{l}\text { No of Explants } \\
\text { Culture }\end{array}$ & $\begin{array}{l}\text { Explants } \\
\text { Bleached }\end{array}$ & $\begin{array}{l}\text { Explants } \\
\text { with callus Shoots }\end{array}$ & $\begin{array}{l}\text { Mean No of } \\
\text { Shoots/Explants (S.E\}* }\end{array}$ \\
\hline Leaf** & ----- & 40 & --------- & $3.0 \pm 1.0$ & $7.3 \pm 0.3$ \\
\hline Leaf & LBA4404 & 40 & 15 & $15 \pm 03$ & $2.3 \pm 2.0$ \\
\hline
\end{tabular}

* Mean \pm Standard Error, ** on Normal Regeneration Medium

\section{Discussion:-}

We have achieved the successful genetic transformation mediated by A. tumefaciens strain LBA-4404 which has a binary vector pBIN 19 derivative with an intron containing GUS gene. The successful transformation was also reported in a number of Solanaceous species Solanum melongena (Flippone and Lurquin, 1989: Rotino and Gleddie, 1990; Leon et al., 1993; Fari et. al., 1995) S. sismbrifolium (Rao et al., 1997) S. muricatum (Atkinson and Gardner, 1991), S. tuberosum (Sheerman and Bevan, 1988); Lycoperiscon esculentum (Hood et.al., 1986a) Capsicum annum (Liu et.al., 1990); Nicotina tobacum (Hood et.al., 1986) and produced transgenic plants. Transformation efficiency was found to be higher in other Solanaceous plants. This transformation efficiency is dependent on various factors type of explants, size, explants orientation on selective regeneration medium, gelling agent and plate sealed and the frequency of transfer to fresh selective medium. Frary and Earle (1996) have examined the effect of various factors on efficiency of Agrobacterium-mediated transformation in L. esculentum cv. Money maker using cotyledon and hypocotyls explants.

Mc Cormick (1991) has reported that the leaf explants were more efficient in generating transgenic shoots as observed in the present investigations. Whereas Liu et al., (1990) has reported that the transformation efficiency was higher in leaf followed by hypocotyls and cotyledon explants and also noted the same differential response between the A. tumefaciens strains C58 and A281 used in bell pepper.

The strain C58 showed more transformation efficiency compared to A 281 in all the explants co-cultivated. Although most published protocols report the use of whole cotyledons as explants (Davis et. al., 1991; Mc Cormick, 1991), cutting cotyledons into two or three pieces (depending) on their size is recommended as a way to maximize the number of transformants obtained from a minimum number of seedlings (Fray and Earle, 1996). Armstead and Webb (1987) found that cotyledons of Lotus corniculatus were more readily transformed than leaves from seedlings grown in vitro. Young leaves were transformed more frequently than old leaves.

However, leaves from old papaya plants were found to be more easily transformed than cotyledons or leaves from young plants (Pang and Sanford, 1988). Agrobacterium- mediated genetic transformation efficiency is not only genotype dependent but also varies with the strains used. The stable integration of GUS and NPT II genes in Mentha arvensis and Mentha spicata has been achieved by A. tumefacies mediated gene transfer. Differences in transformation efficiency between $M$. spicata and $M$. arvensis became apparent in the percentage of explants producing Kanamycin resistant (Km R) calli for the two Agrobacterium strains used. M. spicata explants produced $53 \% \mathrm{KmR}$ calli with GV 2260/GL and 71\% with EHA 105/MOG whereas 5\% and 1.2\% M. arvensis KmR calli were obtained respectively with GV 2260/GI and EHA 105/MOG (Diemer et. al., 1991) reported the difference in degree of transformation caused by three different A. tumefaciens strains, pTi-A6 related plasmids (i.e., those in A6 and A66) have less expression of vir genes than pTiBO 542 plasmids (i.e., those in strain A 281).

Hussain et.al., (1997) also reported in two varieties of Chick pea (6153 and CM72), Agrobacterium strain A281 was found to be more efficient in transformation than C58 Strain A281 was found to be more efficient in transformation than C58. Schroeder et. al., (1993) reported that presence of growth regulators in the co-cultivation medium enhanced transformation frequency in Pisum. Venkatachalam et.al., (2000) have also found an important factor for efficient transformation in Arachis hypogaea was the 2-day pre culture of the cotyledon explants, which probably served to reduce wound stress and increased the number of competent cells at the wound site.

Similar results were also reported in other species by Muthukumar et. al., (1996). Davis et. al., 1991 have studied the effect of tomato cultivar, leaf age and bacterial strain and density of bacterial inoculum on transformation by $A$. tumefaciens and reported the variation in transformation frequencies based on those factors. Plant cultivar was also found to have an 85-fold higher transformation rather than another (Eapen-Kohler et. al., 1987). Petunia nurse cell 
culture technique also enhances the efficiency of A. tumefaciens mediated transformation. Recently, Rama Swamy et. al., (2001) have reported the high transformation efficiency $(96 \%)$ with petunia nurse cell suspension feeder layer culture compared to without feeder layers in leaf discs of Nicotiana tobacum cv. Sunsun. Acetosyringone (AS) is a phenolic compound released by wounded cells and it plays an important role in the natural infection of plants by $A$. tumefaciens as it activates the virulence genes of the Ti-plasmid and initiates the transfer of the T-DNA region to the plant DNA. Exogenous addition of AS in the medium has shown to increase Ti transformation frequencies with Allium cepa, Antirrhinum majus, Arabidopsis thaliana, Atropa belladonna, Brassica compestris, Glycine mad, Nicotiana tabacum and pickling cucumber (Mathews et. al., 1990; Godwin et. al., 1991: Sarmento et. al., 1992). Frary and Earle (1996) have also reported the enhanced transformation in tomato when the explants (cotyledons and hypocotyls segments) co-cultivated in the presence of AS showed the npt II gene more efficient expression than control transformants. Furthermore, regeneration efficiency from transformed explants of Solanum melongena was enhanced by using growth regulators, such as TDZ and antibiotics like augmentin (300 $\mu \mathrm{g} / \mathrm{ml})$ (Billings et. al., 1997).

Agronomically important characters have been genetically engineered in major crop plants using Agrobacterium mediated genetic transformation. Hinchee (1988) first time achieved the successful recovery of transformed Soyabean plants for engineering herbicide resistance. After words, this transformation technology was used for introducing agronomically important traits for improvement of the crop in the following species using Agrobacterium: sugar beet (Herbicide tolerance -D'Halluin et. al., 1995), cotton (Insect resistance, Herbicide tolerance Umbeck 1987), Papaya (virus resistance - Fitsch et. al., 1993), poplar (Herbicide resitance - Filatti, 1988), Potato (Insect resistance, virus resistance, herbicide tolerance, - Van den Elzen et. al., 1995), and tomato (Delayed ripening (increased shelf life), virus resistance - (Sanders et. al., 1992; Redenbaugh et. al., 1993; Reed et. al., 1995). Kemper et. al., (1992) have developed the transgenic Arabidopsis thaliana which are methatrexate resistant due to integration of T-DNA vectors containing a Chimeric dihydrofolate redudctase gene.

Lawrence and Koundal (2001) have developed the transgenic pigeonpea resistant to chewing insects mainly pod borers using A. tumefaciens strain GV 2260 containing the construct of isolated cowpea protease inhibitor gene (pCPI). The Indian Council of Agricultural Research (ICAR) has developed biotech plant types of cotton, Brinjal and tomato and now working on evolving similar plants of rice, chickpea an pigeon and thus, over 35 genetically improved plants created this way. Trials have also been going on in various laboratories to introduce important traits such as herbicide tolerance, virus, abiotic stress and disease resistance including "nif” genes in cereals viz., maize, sorghum and oryza using this A. tumefaciens.

After transfer of the gene of interest using A. tumefaciens the transgene expression is also an important one. The trasgene expression in transgenic populations can vary due to dominant effect exerted by neighbouring plant sequences such as enhancers and silencers may also influence the activity of the introduced genes. Breyene et. al., (1992a) have studied the influence of the T-DNA configuration on inter-transformant expression variability of a reporter gene. The transcriptional interference can diminish the activity of a gene located downstream in opposite orientation (Ingelbrecht et. al., 1991).

Breyene et. al., (1992a) have introduced an additional 3 'nos region between the transgene and the RB (right border) in such an orientation that it would stop possible trancscripts coming from the flanking plant DNA. The presence of 3 'nos resulted in transgenic population with 1.5 to 2 -fold higher mean gus ' $A$ ' proximinity of the ' $35 \mathrm{~S}$ ' enhancer sequences to 'Pnos' results in an increase of Gus' $A$ ' expression. Other molecular causes such as the local DNA structure and / or the higher- order chromatin arrangement (Breyene et. al., 1992 b) possibly also have an important role in the overall level of gene expression.

In view of the importance of A. tumefaciens mediated genetic transformation; the protocol which was developed during the present studies can be utilized to transfer genes of interest for genetic improvement of medicinally important herb $S$. torvum

\section{Conclusion:-}

We demonstrated that Agrobacterium-mediated genetic transformation in S. torvum for the first time. The frequency of genetic transformation conducted by the system established in this study was lower than the reported frequency by floral-dip method (Curtis and Nam 2001; Curtis et al. 2002). However, Agrobacterium method is more popular than floral-dip method for higher plants so as to enable this method to be more rapidly improved. Therefore, genetic 
transformation of S. torvum by Agrobacterium method could also be further developed. Agrobacterium mediated genetic transformation would be applicable to improvement of this crop including development of pathogenresistant cultivars.

\section{References:-}

1. Armstead IP and Webb K. (1987). Effect of age and type of tissue on genetic transformation of Lotus corniculatus by Agrobac terium tumefaciens. Plant Cell Tissue Organ Culture, 9: 95-101.

2. Arulmozhi B and Ramanujam MP (1997) In vitro culture of Solanum trilobatum L. J. Swamy Bot. Club. 14(1\&2): 55-56.

3. Atkinson, RG and Gardner, R.C. (1991). Agrobacterium mediated transformation of pepino and regeneration of transgenic plants. Pl. Cell. Rep., 10: 208-12.

4. Billings, S.; Jelenkovic, G.; Chin, C-K. \& Eberhadt, J.(1997). The effect of growth regulation and antibiotics on eggplant transformation. Journal of the American Society for Horticultural Science 122: 158162

5. Breyne, P., Gheysen, G., Jacobs, A., Van Montagu, M. and Depicker, vA. (1992b) Effect of T-DNA configuration on transgene expression. Mol. Gen. Genet. 235, 389-396.

6. Breyne, P., Van Montagu, M., Depicker, A. and Gheysen, G. (1992a) Characterisation of a plant Scaffold attachment region in a DNA fragment that normalizes transgene expression in tobacco. Plant Cell, 4, 463-471.

7. Cardi, T., D’Ambrosio, F., Consoli, D., Puite, K.J., and Ramulu, K.S. 1993b. Production of somatic hybrids between frost-tolerant Solanum commersonii and $S$. tuberosum: characterization of hybrid plants. Theor. Appl. Genet., 87: 193-200

8. Curtis IS, Nam HG (2001) Transgenic radish (Raphanus sativus L. longipinnatus Baily) by floral-dip method-plant development and surfactant are important in optimizing transformation efficiency. Transgenic Res 10: 363-371

9. Curtis IS, Nam HG, Yun JY, Seo KH (2002) Expression of an antisense GIGANTEA (GI) gene fragment in transgenic radish causes delayed bolting and flowering. Transgenic Res 11: 249-256

10. D'Halluin K. , (1995). Transformation of sugar beet (Beeta vulgris L.) and evaluation of herbicide resistance in transgenic plants. Biotechnology, 10: 309-314.

11. Davis M., Linebeerger R.D. and Miller A.R. (1991). Effects of tomato cultivar, leaf age and bacterial strain on transformation by Agrobacterium tumefaciens. Plant Cell Tissue Org. Cult., 24: 115-121.

12. Diemer F., Caissard J.C., Moja S. and Jullien F. (1991). Agrobacterium tumefaciensmediated transformation of Mentha spicata and Mentha arvensis. $\quad$ Plant Cell Tissue Org. Cult., 57: 75 -78.

13. Eapen S. Kohler F.Gardmann M. and Schiedu O. (1987). Cultivar dependence of transformation rates in moth bean after Co- cultivation of protoplasts with Agrobacterium tuefaciens. Theor Appl. Gent. 75: 207- 210.

14. Fari M., Csanyl M., Mityko J., Peredi A., Szasy A. and Csillag A. (1995a). An alternative pathway of in vitro organogenesis in higher plants: Plant vegetables genera. Hort. Sci., 27: 9-16.

15. Fári, M.; Nagy, I.; Csányi, M.; Mitykó, J. \& Andrásfalvy, A. (1995).Agrobacterium mediated genetic transformation and plant regeneration via organogenesis and somatic embryogenesis from cotyledon leaves in eggplant (Solanum melongena L. $\quad$ cv. 'Kecskemeti lila'). Plant Cell Reports 15: 82-86

16. Filatti, J.J., J. Selmer, B. McCown, B. Haissig, and L. Comai. 1987. Agrobacterium- mediated transformation and regeneration of Populus. Mol. Gen. Genet. 206:192- 99

17. Fillipone, E. \& Lurquin, P.F. (1989). Stable transformation of eggplant (Solanum melongena L.) by cocultivation of tissues with Agrobacterium tumefaciens carrying a binary plasmid vector. Plant Cell Reports 8: 370-373.

18. Fitch M.M.M. et al., (1993). Transgenic papaya plants from Agrobacterium mediated transformation of somatic embryos. Plant Cell Rep., 12: 245- 249

19. Frary A. and Earle E.D. (1996). An examination of factors effecting the efficiencyof Agrobacterium mediated transformation of tomato. Plant Cell Rep., 16: 235-240.

20. Gelvin, S. B. (2003). Agrobacterium-Mediated Plant Transformation: the Biology behind the "Gene Jockeying" Tool. Microbiology and Molecular Biology Reviews 67(1): $\quad$ 16-37.

21. George, L., V. A. Bapat, and P. S. Rao. (1987). In vitro multiplication of sesame (Sesamuni indicum) through tissue culture. Ann. Bot. 60: 17-21. 
22. Godwin, L., G. Todd, B. Ford-Lloyd, and H. J. Newbury. (1991). The effects of acetosyringone and pH on Agrobacteriurn-mediated transformation vary according to plant species. Plant Cell Rep. 9(12): 67 1-675.

23. Gupta, S.C. and Handra, N. (1982). Control of organogenesis in culture of leaf, multilayerd strips and segments of stem and root in Solanum surattense Burm. Indian j. Exp. Biol. 20: 126-131.

24. Hendrix, C.R., Litz, E.R. \& Kirchoff, K.B. (1987). In vitro Organogenesis and plant regeneration from leaves of Solanum candidum Lindl. S. quitoens Lam.' (naranjilla) and S. sessiliflorum Dunal. Plant Cell, Tissue and Organ Culture, 11: 67-73.

25. Henriques, A.T., Kerber, V.A., Moreno, P.R.H., 2002. Alcalo’ides: generalidades e aspectos ba'sicos. In: Simo es, C.M.O., Schenkel, E.P., Gosmann, G., Mello, $\quad$ J.C.P., Mentz, L.A., Petrovick, P.R. (Eds.), Farmacognosia-da planta ao medicamento, fourthed. Editora Universita'ria/UFRGS/UFSC, Porto Alegre/Floriano'polis, pp. 641-656.

26. Henriques, A.T.; Kerber, V.A.; Moreno, P.R.H. (2002) Alcalóides: generalidadese aspectos básicos. In: Simoes, C.M.O. et al.( 2002) (Ed.). Farmacognosia: da planta ao medicamento. Porto Alegre/Florianópolis: UFRGS/ UFSC, p.651-6.

27. Hinchee, M. A. W., D. V. Connor-Ward, C. A. Newell, R. E. McDonell. S. J. Sato. C. S. Gasser. D. A. Fischhoff, D. R. Re, R. T. Fraley, and R. B. Horsch. (1988). Production of transgenic soybean plants using Agrohacteriuni-mediated DNA transfer. Biotechmology 6: 915-922.

28. Hinchee, M. A. W., et al. (1988). Production of Transgenic Soybean Plants Using Agrobacterium-Mediated DNA Transfer. Nat Biotech, 6(8), 915-922.

29. Hood E.E., Helmer G.L., Fraley R.T. and Chilton M.D. (1986). The hyper virulence of Agrobacterium tumefaciens A 281 is encoded in a region of pTiBO 542 outside of TDNA. J. Bacteriol, 168: 1291-1301.

30. Hughes, E.H.; Shanks, J.V.( 2002) Metabolic engineering of plants for alkaloid production. Metabolic Engineering, v.4, p.41-8

31. Hussain T., Malik T., Raziuddin S. and Gordon M.P. (1997). Studies on the expression of marker genes in chick pea. Plant Cell Tissue Org. Cult., b49: 7-16.

32. Ingelbrecht I., Breyne P., Vancompernolle K., Jacobs A. Van Montagu M., Depicker A. Experimental analysis of transcriptional interference in transgenic plants. Gene, 109: 239-242.

33. Jelenic, Srecko, Mitrikwski, Petar T., Papes Drazena and Jelaska Sinila, (2000). Transformation of Broad Bean. Food Technology and Biotechnology 38(3): 167- 172.

34. Kemper E., Grevelding Ch., Schell J. and Masterson R. (1992). Improved method for the transformation of Arabidopsis thaliana with chimeric dihydrofolate reductase constructs which confer methotrexate resistance. Plant Cell Rep., 11: 118-121.

35. Langeland KA, Burks KC. (1998) Identification and Biology of Non-Native Plants in Florida's Natural Areas. University Press of Florida, Gainesville, FL, 1998.

36. Lawrence P.K. and Koundal K.R. (2001).Agrobacterium tumefaciens mediated transformation of pigeon pea (Cajanus cajan L. Mill. Sp.) and molecular analysis of regenerated plants. Curr. Sci., 80: 1428-1432

37. Leone M., Filippone E. and Lurquin P.F. (1993). Transformation in Solanum melongena L (egg Plant ). In : Bajaj (ed.) Biotechnology in Agriculture and Forestry: Plant Protoplasts and genetic engineering (pp. 320-328), Springer, Verlag- Berlin, Germany.

38. Liu W., Parrott W.A., Hildebrand D.F., Collins G.B. and Williams E.G. (1990). grobacterium induced gall formation in bell pepper (Capsicum annum L.) and formation of shoot - like structures expressing introduced gens. Plant Cell Rep., 9: 60- 364.

39. Madhavan S, Balu S (1999) Ethnobotanical studies on Solanum trilobatum Linn. an Indian drug plant. J Econ Taxon Bot 23(1999):43-46

40. Mathews H., Bharathan N., Litz R.E. Narayanan K.R., Rao P.S., Bhatia C.R. ( 1990). Plant Physiol., 136: 404-409.

41. McCormick S.(1991). In: Plant Tissue Culture Manual Fundamentals and Applications (ed). Lindsley. K Kulwer Acad. Publ., Dordrecht, The Netherlands, pp. B6 1-9.

42. Mukherjee SK, Sabapathi RB, Gupta N. (1991). Low sugar and osmotic requirements for shoot regeneration from leaf pieces of Solanum melongena L. Plant Cell Tiss $\quad$ Org Cult. 25: 13-1 6

43. Muthukumar B., Mariamma M., Veluthamfi K. and Gnanam A. (1996). Plant Cell Rep., 15: 980985.

44. Nisbet, G. S. and K. J. Webb. (1990). In: Biotechnology in Agriculture and Forestry: $\quad$ Legumes and Oilseed Crops. (Ed. Baja, Y. P. S.). Springer-Verlag. Berlin. 10(1): $\quad 3$ 8-48.

45. Pang S.Z. and Sanford J.C. (1988). Agrobacterium mediated gene transfer in papaya. J. Amer. Soc. Hort. Sci., 133: 287-291. 
46. Pierik, R.L.M. (1987). “In vitro culture of higher plants”. Martinus nightoff, Dordrecht. $\quad$ pp. 183-230

47. Rao A.V., Venu Ch. and Sadanadam A. (1997). Selection of streptomycin \& Kanamycin Resistance using nitrosomethylorea \& Agrobacterium in Solanum sisymbrifolium.Indian J. Exptl. Biol., 35: $188-192$.

48. Rastogi, S., Dwivedi, U.N., (2006). Down-regulation of lignin biosynthesis in transgenic Leucaena leucocephala harboring o-methyltransferase gene. Biotechnol. Prog. 22, 609- 616.

49. Redenbaugh K. et al., (1993). Regulatory issues for commercialization of tomatoes with an antisense polygalacturonase gene. In Vitro Cell Dev. Biol., 29: 17-26.

50. Reed A.J., Magin K.M., Anderson J.S., Austin G.D., Rangwala T., Linde D.C. Love $\quad$ J.N., $\quad$ Rogers S.G. and Fuchs R.L. (1995).J. Agri. Fol. Chem., 43: 1954-1962. Rotino, G.L. \& Gleddie, S. 1990. Transformation of eggplant (Solanum melongena L.) using a binary Agrobacterium tumefaciens vectors. Plant Cell Reports 9: 26-29.

51. Sanders P.R. et al., (1992). Field resistance of transgenic tomatoes expressing the tobacomosaic virus coat protein gene. Phytopathology, 82: 683- 690.

52. Sarmento G.G., Alpert K. Tang F.A., Punja Z.K. (1992).Plant Cell Tissue Org. Cult., $31: 185-193$.

53. Schroeder H.E., Schotz A.H., Wardley-Richardson T., Spencer D. and Higgins T.J.V. (1993). Plant Physiol., 101: 751- 757.

54. Sheerman S and Bevan MW (1988). “A rapid transformation method for Solanum tuberosum using Agrobacterium tumefaciens vectors". Plant Cell Rep. 7: 13- 16.

55. Toriyarna, K., J. C. Stein, M. E. Nasraflah, and J. B. Nasrallah. (1991). Transformation of Brassica oleracea with an S-locus gene from B. campestris Appl. Genet. 81: 769-776.

56. Umbeek P., et al., (1987). Genetically transformed cotton (Gossypium hirsutum L) plants. Biotech, 5: 263266.

57. Van Rockel J.C., Damm B., Melchers L.S. and Hoekema A. (1993).Plant Cell Rep., $12: 644-647$.

58. Vanden Elzen P.J.M. et al., (1995). Virus and Fungal resistance: From laboratory to field Philos Trans Roy Soc. London. Ser. B., 342: 271- 278.

59. Venkatachalam P., Geetha N., Khandelwal A, Shaila M.S. and Lakshmisita, G. (2000). Agrobacterium mediated genetic transformation and regeneration of transgenic plants from cotyledon explants of ground nut (Archis hypogea L). Via, Somatic embryogenesis Curr. Sci, 78: 1130-1136.

60. Weber, S., W. Friedt, N. Landes, J. Molinier, C. Himber, P. Rousselin, G. Hahne, $\quad$ and R. Horn. (2003). Improved Agrohacterium-mediated transformation of $\quad$ sunflower $\quad$ (Helianthus annus L.): assessment of macerating enzymes and sonication. Plant Cell Rep. 21(5): 475-482. 